\title{
Author Correction: Microglia-specific overexpression of $\alpha$-synuclein leads to severe dopaminergic neurodegeneration by phagocytic exhaustion and oxidative toxicity
}

Simone Bido (1), Sharon Muggeo (1), Luca Massimino, Matteo Jacopo Marzi, Serena Gea Giannelli, Elena Melacini, Melania Nannoni, Diana Gambarè, Edoardo Bellini D, Gabriele Ordazzo, Greta Rossi, Camilla Maffezzini, Angelo lannelli, Mirko Luoni, Marco Bacigaluppi, Silvia Gregori, Francesco Nicassio (i) \& Vania Broccoli (i)

Correction to: Nature Communications https://doi.org/10.1038/s41467-021-26519-x, published online 29 October 2021.

The original version of this Article contained an error in the spelling of the author Marco Bacigaluppi, which was incorrectly given as Marco Bagicaluppi. This has now been corrected in both the PDF and HTML versions of the Article.

Published online: 16 December 2021

(c) (i) Open Access This article is licensed under a Creative Commons Attribution 4.0 International License, which permits use, sharing, adaptation, distribution and reproduction in any medium or format, as long as you give appropriate credit to the original author(s) and the source, provide a link to the Creative Commons license, and indicate if changes were made. The images or other third party material in this article are included in the article's Creative Commons license, unless indicated otherwise in a credit line to the material. If material is not included in the article's Creative Commons license and your intended use is not permitted by statutory regulation or exceeds the permitted use, you will need to obtain permission directly from the copyright holder. To view a copy of this license, visit http://creativecommons.org/licenses/by/4.0/.

() The Author(s) 2021 